\title{
Optimasi Formula Sediaan Krim o/w Kombinasi Oksibenzon dan Titanium Dioksida Serta Uji Aktivitas Tabir Suryanya Secara In Vivo
}

\author{
Formula Optimization of $o / w$ Cream Combination Oxybenzone and Titanium \\ Dioxide and Its In Vivo Activity Testing
}

\section{Ribka Elcistia, Abdul Karim Zulkarnain*}

Fakultas Farmasi, Universitas Gadjah Mada Yogyakarta

Corresponding author: Abdul Karim Zulkarnain: Email: akarimzk08@gmail.com

\begin{abstract}
ABSTRAK
Efek buruk dari sinar matahari dapat dikurangi dengan penggunaan tabir surya. Optimasi emulgator trietanolamin (TEA) stearat dan setil alkohol pada krim tabir surya kombinasi oksibenzon dan titanium dioksida diharapkan menghasilkan formula optimum krim dengan stabilitas fisik yang baik. Tujuan penelitian ini yaitu mengetahui proporsi TEA stearat dan setil alkohol formula optimum dan nilai SPF krim $o / w$ kombinasi oksibenzon dan titanium dioksida. Penetapan formula optimum dilakukan pada data uji sifat fisik krim menggunakan metode Simplex Lattice Design design software Design Expert version 9.0.4. Uji one sample t-test dilakukan untuk mengetahui perbedaan nilai antara formula optimum yang dihasilkan software Design Expert version 9.0.4 dengan hasil percobaan. Perbandingan sifat fisik formula optimum krim o/w kombinasi oksibenzon dan titanium oksida selama penyimpanan 4 minggu dianalisis menggunakan uji ANOVA. Pengujian nilai SPF secara in vivo dilakukan pada kelinci betina galur New Zealand White terinduksi senyawa 8metoksiprosalen. Hasil penelitian menunjukkan proporsi TEA stearat dan setil alkohol yang menghasilkan formula optimum krim $o / w$ kombinasi oksibenzon dan titanium dioksida adalah $8.93 \%$ dan $2.07 \%$. Sifat fisik viskositas dan daya lekat tidak berbeda signifikan, sedangkan daya sebar berbeda signifikan selama penyimpanan 4 minggu. Pengujian aktivitas tabir surya secara in vivo krim $o / w$ kombinasi oksibenzon dan titanium dioksida menghasilkan nilai SPF 12.
\end{abstract}

Kata kunci: oksibenzon, titanium dioksida, tabir surya, in vivo

\begin{abstract}
The downside effects from sunlight exposure can be reduced by using sunscreen. Emulsifier optimization of triethanolamine (TEA) stearate and cetyl alcohol in sunscreen cream containing combination of oxybenzone and titanium dioxide is expected to produce the desired cream optimum formula with good physical stability. This study aimed to determine the optimum TEA sterate and cetyl alcohol proportion and figure out the SPF value of $\mathrm{o} / \mathrm{w}$ cream containing combination of oxybenzone and titanium dioxide. The optimum formula was obtained based on cream physical characteristics testing with Simplex Lattice Design method using software Design Expert version 9.0.4. One sample ttest was used to determine the difference of optimum formula value between research and software Design Expert version 9.0.4 analysis. The comparison between optimum formula $\mathrm{o} / \mathrm{w}$ cream combination oxybenzone and titanium dioxide during 4 weeks storage was analyzed using ANOVA test. The SPF value testing through in vivo was conducted against female rabbits strain New Zealand White induced by 8 -methoxyprosalen. The result
\end{abstract}


showed that proportion TEA stearate and cetyl alcohol which produced the optimum formula of $\mathrm{o} / \mathrm{w}$ cream combination oxybenzone and titanium dioxide were $8.93 \%$ and $2.07 \%$. The viscosity and adhesiveness were not siginifically different, while cream spreadability was significally different during 4 weeks storage. Testing activity in vivo sunscreen cream o / w combination of oxybenzone and titanium dioxide produced SPF 12.

Keyword: oxybenzone, titanium dioxide, sunscreen, in vivo

\section{PENDAHULUAN}

Sinar matahari terdiri dari panjang gelombang mulai dari sinar ultraviolet (UV) hingga sinar tampak (Hansol et al., 2006). Jumlah sinar UV yang terkandung dalam total radiasi matahari adalah sekitar $10 \%$. Sinar UV dibagi menjadi tiga kategori berdasarkan panjang gelombangnya, yaitu U V-C (270-290 nm), UV-B (290-320 nm), dan UV-A (320-400 nm). UV-C diserap oleh lapisan ozon, sedangkan UV-B dan UV-A dapat mencapai permukaan bumi (Amnuaikit \& Boonme, 2015).

Dampak positif dari sinar UV antara lain kehangatan, cahaya, dan sintesis vitamin D pada kulit (Holick et al., 1980). Dampak negatif sinar UV antara lain menyebabkan sunburn yang ditandai dengan gejala iritasi ringan hingga inflamasi akut. Radiasi sinar UV yang berlebihan akan menghancurkan vitamin D pada lemak kulit sehingga mengubahnya menjadi toxic steroid dan mengakibatkan degenerasi jaringan ikat kulit dan munculnya kerutan (Jellinek, 1970); faktor risiko penyakit mata (Sliney, 2001); serta menurunkan kekebalan tubuh (Norval, 2006). Efek jangka panjang paparan radiasi UV yang berlebihan mampu memicu terjadinya kanker kulit (Hussein, 2005).

Salah satu cara untuk melindungi kulit dari paparan sinar matahari adalah dengan menggunakan sediaan tabir surya (Benson, 2007). Berdasarkan metode proteksinya, tabir surya terbagi menjadi tabir surya kimia dan fisik (Draelos \& Thaman, 2006). Tabir surya kimia umumnya digunakan dalam kombinasi karena tidak ada agen aktif tunggal sesuai dengan level konsentrasi yang saat ini diizinkan oleh undang-undang yang mampu memberikan perlindungan yang memadai terhadap UV (Diaz-Cruz et al., 2008).

Salah satu senyawa yang banyak digunakan dalam sediaan tabir surya di pasaran adalah oksibenzon (Correa et al., 2012). Oksibenzon merupakan agen tabir surya kimia yang memiliki kemampuan absorbsi terhadap UV-A dan UV-B, walaupun absorbsi pada UV-A nya cukup lemah (Baughman et al., 2009). Pada penelitian ini akan dikombinasikan agen tabir surya kimia yaitu oksibenzon $6 \%$ dan agen tabir surya fisik yaitu titanium dioksida 5\% dengan harapan menghasilkan nilai SPF yang lebih tinggi daripada penggunaan oksibenzon secara tunggal.

Berdasarkan Kim dan Choi (2014), oksibenzon memiliki sifat lipofilik. Pembuatan formula krim oksibenzon dan titanium dioksida dengan tipe emulsi oil in water $(o / w)$ dalam penelitian ini akan dibuat oksibenzon berada dalam fase dalam yaitu minyak, sehingga stabilitas senyawa terlindungi oleh fase luar. Selain itu, kelebihan krim tipe $o / w$ antara lain tidak lengket dan mudah dicuci dengan air (Ansel, 2005). Emulgator untuk mencampurkan fase minyak dan fase air. Emulgator yang digunakan adalah trietanolamin (TEA) stearat. Asam stearat bereaksi dengan TEA secara insitu menghasilkan suatu garam, yaitu TEA stearat yang berfungsi sebagai emulgator untuk tipe emulsi tipe m/a (Aulton, 2002).

Optimasi digunakan untuk memperkirakan jawaban dari suatu fungsi variabel-variabel respon yang dihasilkan dari rancangan percobaan yang dilakukan sehingga menghasilkan formula optimum. 
Tabel I. Formula Krim $o / w$ Kombinasi Oksibenzon dan Titanium Dioksida dengan Variasi TEA. Stearat dan Setil Alkohol

\begin{tabular}{lllllllll}
\hline Bahan (\%) & F1 & F2 & F3 & F4 & F5 & F6 & F7 & F8 \\
\hline Oksibenzon & 6 & 6 & 6 & 6 & 6 & 6 & 6 & 6 \\
Titanium Dioksida & 5 & 5 & 5 & 5 & 5 & 5 & 5 & 5 \\
Dimethicone & 4 & 4 & 4 & 4 & 4 & 4 & 4 & 4 \\
Mineral Oil & 2,2 & 2,2 & 2,2 & 2,2 & 2,2 & 2,2 & 2,2 & 2,2 \\
Asam Stearat & 6,25 & 6,88 & 7,5 & 5 & 5 & 6,25 & 7,5 & 5,63 \\
TEA & 1,25 & 1,38 & 1,5 & 1 & 1 & 1,25 & 1,5 & 1,13 \\
Setil Alkohol & 3,5 & 2,75 & 2 & 5 & 5 & 3,5 & 2 & 4,25 \\
Gliserin & 1,8 & 1,8 & 1,8 & 1,8 & 1,8 & 1,8 & 1,8 & 1,8 \\
Metilparaben & 0,2 & 0,2 & 0,2 & 0,2 & 0,2 & 0,2 & 0,2 & 0,2 \\
Akuades & 69,8 & 69,8 & 69,8 & 69,8 & 69,8 & 69,8 & 69,8 & 69,8 \\
\hline
\end{tabular}

Simplex lattice design merupakan suatu metode yang dapat digunakan untuk menentukan proporsi relatif bahan-bahan yang digunakan dalam suatu formula sehingga diharapkan akan dapat dihasilkan formula yang paling baik sesuai dengan kriteria yang ditentukan (Kurniawan \& Sulaiman, 2009). Optimasi formula krim $o / w$ kombinasi oksibenzon dan titanium dioksida menggunakan metode Simplex Lattice Design menggunakan software Design Expert version 9.0.4 pada program mixture design dengan komponen variasi TEA stearat dan setil alkohol sehingga diharapkan menghasilkan stabilitas fisik krim yang baik selama penyimpanan.

Pengujian SPF secara in vivo walaupun lebih mahal dan memakan waktu, namun memberikan hasil yang lebih reliable dan akurat dibanding metode in vitro. Oleh sebab itu, nilai SPF formula optimum krim $o / w$ kombinasi oksibenzon dan titanium dioksida pada penelitian ini akan ditentukan dengan metode in vivo menggunakan hewan uji kelinci betina galur New Zealand White terinduksi senyawa 8-metoksiprosalen.

\section{METODOLOGI}

\section{Bahan dan Alat}

Oksibenzon (Merck) dan titanium dioksida. Bahan untuk pembuatan krim $\mathrm{o} / \mathrm{w}$ adalah dimethicone (farmasetis), mineral oil (farmasetis), asam stearat (farmasetis), TEA (farmasetis), setil alkohol (farmasetis), gliserin (farmasetis), metilparaben (farmasetis), dan akuades. Bahan lain yaitu etanol 95\%P, 8 Metoksiprosalen (Sigma-Aldrich.

Neraca analitik (AdventurerTM, Ohaus), stirer, cawan porselen, alat-alat gelas, pipet tetes, waterbath (Memmert $\AA$ ), dan pot krim. Alat untuk uji stabilitas krim adalah stopwatch (ALBA Digital Stopwatch), alat uji daya sebar (Lab. Teknologi Farmasi, Fakultas Farmasi UGM), alat uji daya lekat (Lab. Teknologi Farmasi, Fakultas Farmasi UGM), viskotester VT-04E (RION Co. Ltd, Jepang), conical, oven, kulkas, kertas indikator $\mathrm{pH}$ (MERCK®, Jerman), pencukur bulu, lampu UV Mineralight.

\section{Pembuatan krim}

Semua bahan ditimbang terlebih dahulu. Pertama-tama, dibuat bagian minyak dengan cara melelehkan dimethicone, mineral oil, asam stearat, dan setil alkohol, dalam cawan porselen (a) yang kemudian dipanaskan di atas penangas air sambil diaduk hingga suhu kurang lebih $75^{\circ} \mathrm{C}$. Pada cawan porselen yang lain, dibuat bagian air dengan mencampurkan TEA, gliserin, dan metil paraben kemudian ditambah sebagian akuades dan dipanaskan di atas penangas air hingga suhu $75^{\circ} \mathrm{C}$ (b). Selanjutnya campuran (a) dimasukkan ke dalam gelas beker lalu ditambahkan oksibenzon. 
Setelah tercampur, ditambahkan campuran (b) secara perlahan sambil dilakukan pengadukan konstan sampai homogen dan terbentuk korpus emulsi oleh alat pendispersi. Setelah terbentuk korpus emulsi minyak dalam air, titanium dioksida dimasukkan ke dalam campuran. Campuran diaduk menggunakan stirer berkecepatan 250 rpm selama 25 menit hingga homogen.

\section{Pengujian sifat fisik krim}

Pengujian sifat fisik 8 formula hasil optimasi software Design Expert version 9.0.4 krim $o / w$ kombinasi oksibenzon dan titanium dioksida meliputi organoleptis, homogenitas, viskositas, daya sebar, daya lekat, $\mathrm{pH}$, dan tipe emulsi.

\section{Penentuan formula optimum krim $o / w$ kombinasi oksibenzon dan titanium dioksida}

Penentuan formula optimum dilakukan dengan cara mengolah data hasil pengujian sifat fisik krim $o / w$ kombinasi oksibenzon dan titanium dioksida hasil percobaan dengan menggunakan software Design Expert version 9.0.4. Parameter fisik yang digunakan yaitu viskositas, daya sebar, dan daya lekat. Target respon dan derajat kepentingan disesuaikan untuk memperoleh kombinasi TEA-Stearat dan setil alkohol yang optimal.

\section{Verifikasi formula optimum krim $o / w$ kombinasi oksibenzon dan titanium dioksida}

Formula optimum yang dimunculkan oleh software Design Expert version 9.0.4 diformulasikan menjadi sediaan krim dengan metode yang sama dengan delapan formula sebelumnya. Krim formula optimum kemudian diuji sifat fisiknya pada minggu ke-0 dan dibandingkan dengan nilai prediksi sifat fisik dari software Design Expert version 9.0.4. Parameter sifat fisik yang digunakan meliputi viskositas, daya sebar, dan daya lekat. Analisis statistik untuk verifikasi menggunakan one sample ttest dengan taraf kepercayaan 95\% yang bertujuan untuk mengetahui apakah prediksi yang dihasilkan oleh software Design Expert version 9.0.4 menghasilkan data yang berbeda signifikan atau tidak terhadap krim hasil percobaan.

\section{Penentuan stabilitas fisik formula optimum krim $o / w$ kombinasi oksibenzon dan titanium dioksida}

Pengujian stabilitas fisik formula optimum krim $o / w$ kombinasi oksibenzon dan titanium dioksida meliputi viskositas, daya sebar, daya lekat, $\mathrm{pH}$, tipe emulsi, dan cycling test selama 4 minggu penyimpanan.

\section{Uji viskositas}

Viskositas krim ditetapkan dengan viscotester VT-04E (Rion Co, Ltd), rotor no 1. Pengukuran dilakukan dengan cara sediaan dimasukkan dalam wadah, kemudian dipasang pada portable viscotester. Nilai viskositas diketahui dengan mengamati gerakan jarum penunjuk hingga stabil dan menunjukkan angka tertentu (Marchaban et al., 2016).

\section{Uji daya sebar}

Setengah gram krim diletakkan di tengah-tengah kaca bulat. Kemudian ditutup dengan kaca lain yang telah ditimbang terlebih dahulu dan dibiarkan 1 menit. Krim yang menyebar diukur diameternya dengan mengambil panjang rata-rata diameter dari beberapa sisi. Di atasnya ditambahkan beban 50 gram, dibiarkan 1 menit dan diukur diameter sebarnya. Diteruskan penambahan beban tiap kali sebesar 50 gram hingga 250 gram, setelah 1 menit diukur hingga diperoleh diameter yang cukup untuk melihat pengaruh beban terhadap perubahan diameter sebar krim (Voigt, 1984).

\section{Uji daya lekat}

Seratus miligram krim diletakkan di antara dua obyek glass yang telah ditentukan luasnya $(2 \times 2,5 \mathrm{~cm})$. Di atasnya, ditekan dengan beban $1 \mathrm{~kg}$ selama 5 menit. Kemudian, obyek glass dipasang pada alat 
tes, beban 21 gram dilepaskan dan dicatat waktu hingga kedua obyek glass tersebut terlepas (Marchaban et al., 2016).

\section{Uji pH}

Pengukuran $\mathrm{pH}$ sediaan krim dilakukan dengan menggunakan kertas indikator $\mathrm{pH}$, yaitu dengan cara kertas indikator $\mathrm{pH}$ dicelupkan ke dalam sediaan krim, diamkan sebentar. Selanjutnya kertas indikator $\mathrm{pH}$ yang telah dicelupkan disesuaikan dengan skala warna pada indikator dan amati skala yang terbaca.

\section{Uji tipe emulsi}

Metode yang digunakan untuk mengamati tipe emulsi adalah metode pengenceran, yaitu dengan melarutkan krim dalam air dan minyak (Voigt, 1984). Jika krim dapat larut dalam air, maka krim tersebut merupakan krim $o / w$. Sebaliknya, jika krim larut dalam minyak, maka krim tersebut merupakan krim $w / o$.

\section{Cycling test}

Metode cycling test dilakukan dengan cara sediaan disimpan pada 2 suhu yang berbeda dalam 6 siklus. Sediaan krim dimasukkan ke dalam conical lalu disimpan dalam kulkas pada suhu $4^{\circ} \mathrm{C} \pm 2^{\circ} \mathrm{C}$ selama 24 jam lalu dipindahkan ke dalam oven bersuhu $45^{\circ} \mathrm{C} \pm 2^{\circ} \mathrm{C}$ selama 24 jam. Waktu penyimpanan dua suhu tersebut dalam 2 hari dianggap 1 siklus. Dilakukan pengamatan secara kualitatif terjadinya pemisahan pada tabung conical. Pengamatan dilakukan selama 6 siklus. (Lachman et al., 1994).

\section{Uji aktivitas tabir surya secara in vivo}

Uji aktivitas dilakukan dengan menentukan Sun Protection Factor (SPF) terhadap sinar UV-B secara in vivo yang dilakukan pada kelinci betina. Punggung kelinci dicukur bulunya dan ditandai seluas $5 \times 5 \mathrm{~cm}^{2}$ kemudian kelinci disensitisasi dengan senyawa 8-MOP yang diberikan secara per oral dengan dosis $10 \mathrm{mg} / \mathrm{kgBB}$. Selanjutnya, dilakukan penetuan Minimal
Erythema Dose (MED) dengan menyinari punggung kelinci tanpa perlakuan. Dua puluh empat jam setelah penyinaran, diamati eritema yang timbul pada daerah yang disinari (Kim et al., 2010) . Setelah mendapatkan nilai MED, uji aktivitas tabir surya dilanjutkan dengan mengoleskan krim pada pada punggung kelinci dengan dosis $2 \mathrm{mg} / \mathrm{cm}^{2}$ (Osterwalder \& Herzog, 2009). Nilai SPF diperoleh dari perbandingan nilai MED pada kulit terlindungi tabir surya dengan nilai MED pada kulit yang tidak terlindungi tabir surya (Sambandan \& Ratner, 2011).

\section{HASIL DAN PEMBAHASAN \\ Sifat Fisik Krim $o / w$ Kombinasi Oksibenzon-Titanium Dioksida Organoleptis}

Membuat formulasi sediaan topikal tidak hanya dengan optimasi penghantaran zat aktif tetapi juga harus memenuhi persyaratan stabilitas fisika dan kimia, tidak toksik, dan estetika (Smith et al., 2000). Pengujian organoleptis merupakan pengamatan secara kualitatif meliputi konsistensi, warna, tekstur, dan bau terhadap sediaan krim $o / w$ kombinasi oksibenzon dan titanium dioksida yang dihasilkan. Hasil pengamatan organoleptis terhadap 8 formula krim $o / w$ kombinasi oksibenzon dan titanium dioksida yang dihasilkan menunjukkan karakteristik yang hampir sama yaitu konsistensi kental, warna putih, tekstur lembut, serta bau khas. Serbuk oksibenzon berwarna kuning muda, sedangkan serbuk titanium dioksida berwarna putih. Hasil krim kombinasi oksibenzon dan titanium dioksida berwarna putih disebabkan oleh titanium dioksida yang berwarna putih dan bersifat opak. Titanium dioksida memberikan perlindungan UVB yang baik dan memiliki intensitas warna putih yang pekat.

Viskositas, merupakan salah satu respon optimasi yang penting untuk karakter emulsi yang berbasis krim. Viskositas merupakan parameter yang menggambarkan tentang besarnya tahanan 
suatu cairan untuk mengalir. Semakin besar tahanannya, maka viskositas juga akan semakin besar (Sinko, 2006). Krim dengan viskositas yang terlalu tinggi maka akan sulit dituang ke dalam wadah, sedangkan krim dengan viskositas yang terlalu rendah menghasilkan krim yang encer dan mudah menetes saat diaplikasikan sehingga tidak tinggal seluruhnya pada permukaan kulit (Ningrum, 2011). Oleh sebab itu, viskositas krim yang optimum diperlukan agar diperoleh krim yang nyaman untuk digunakan.

Viskositas krim diukur menggunakan viskotester VT-04 (Rion Co, Ltd). Rotor bernomor 1 digunakan untuk mengukur sediaan dengan viskositas antara 3-150 dPas, sedangkan rotor nomor 2 untuk mengukur sediaan dengan viskositas 100 4000 dPas. Viskositas krim diukur satu hari setelah pembuatan krim untuk menunggu stabilnya pembentukan emulsi dan memberi waktu emulgator untuk bercampur sempurna. Menurut (Langenbucher dan Lange 2007), viskositas yang dapat diterima untuk sediaan semisolid yang menbutuhkan pemencetan dari tube adalah 50-1000 dPas dengan nilai optimumnya 200 dPas. Delapan formula krim yang dihasilkan menunjukkan viskositas yang bervariasi dan masuk ke dalam rentang viskositas yang dapat diterima. Viskositas krim yang paling rendah adalah F3 yaitu $120 \pm 4,59$ dPas, sedangkan viskositas krim yang paling tinggi adalah F8 yaitu $190 \pm 2,11$ dPas. F3 mengandung konsentrasi setil alkohol terendah sehingga viskositasnya paling kecil. Hal ini disebabkan, setil alkohol dapat meningkatkan stabilitas krim $o / w$ dengan mekanisme meningkatkan konsistensi krim dengan adanya emulgator yang larut air (Rowe, 2005). TEA merupakan emulgator yang larut air karena memiliki gugus yang polar, sehingga berinteraksi dengan setil alkohol untuk meningkatkan viskositaskrim.
Daya sebar, sediaan krim merupakan sediaan topikal yang diaplikasikan dengan cara dioleskan. Daya sebar merupakan bagian dari psikoreologi yang dapat dijadikan sebagai parameter aseptabilitas (Martin et al., 1993). Daya sebar yang optimum akan memudahkan krim menyebar saat dioleskan pada permukaan kulit tanpa perlu tekanan yang besar. Pada umumnya daya sebar memiliki kaitan dengan viskositas. Apabila viskositas rendah, maka daya sebar krim akan semakin besar karena krim akan semakin mudah mengalir dan menyebar pada permukaan kulit.

Data hasil pengujian daya sebar dari 8 formula yang dihasilkan menunjukkan krim yang memiliki daya sebar paling besar adalah F3 yaitu luas daya sebarnya 42,06 \pm $2,90 \mathrm{~cm}^{2}$, sedangkan krim dengan daya sebar paling kecil adalah F1 yaitu luas daya sebarnya $27,11 \pm 1,39 \mathrm{~cm}^{2}$. Viskositas terendah ditunjukkan oleh F3. F3 mengandung konsentrasi setil alkhol terendah sehingga menghasilkan sediaan krim dengan viskositas terendah sehingga menghasilkan daya sebar terbesar.

Daya lekat, krim berkaitan dengan seberapa lama kemampuan krim melekat pada kulit. Krim tabir surya harus memiliki daya lekat yang optimum agar efektif dalam melindungi kulit dari paparan sinar matahari namun tetap mudah dihilangkan dengan pencucian menggunakan air. Krim yang terlalu lengket akan tidak nyaman digunakan dan mudah mengabsorpsi debu, sedangkan krim yang tidak lengket memiliki daya proteksi yang singkat sehingga perlu pengulangan pengaplikasian krim. Data hasil pengujian daya lekat dari 8 formula menunjukkan krim yang memiliki daya lekat paling besar adalah F8, sedangkan krim yang memiliki daya lekat paling kecil adalah F7. F7 memiliki daya lekat paling rendah sebab sama halnya seperti F3, setil alkohol yang terkandung paling sedikit. Konsistensi krim F7 dan F3 
agak encer, ditunjukkan oleh nilai viskositas yang rendah sehingga daya lekatnya pun paling kecil.

Pengujian $\mathrm{pH}$ bertujuan untuk mengevaluasi keamanan krim yang dihasilkan sehingga tidak mengiritasi kulit. Sediaan krim yang dihasilkan sebaiknya memiliki $\mathrm{pH}$ yang mendekati $\mathrm{pH}$ normal kulit, yaitu 4,5-6,5 (Draelos \& Thaman, 2006). pH krim yang terlalu asam dapat menyebabkan iritasi pada kulit, sedangkan $\mathrm{pH}$ krim yang terlalu basa dapat menyebabkan kulit bersisik. Penggunaan emolien silikon, dalam formula ini yaitu dimethicone, dapat mengurangi efek kulit kering akibat titanium dioksida atau zink oksida (Draelos \& Thaman, 2006). Kedelapan formula yang dihasilkan masuk ke dalam rentang $\mathrm{pH}$ fisiologis kulit sehingga aman untuk digunakan. Rata-rata sediaan krim $o / w$ kombinasi oksibenzon dan titanium dioksida menghasilkan $\mathrm{pH}$ 6, kecuali F3 dan F7 yang menghasilkan pH 7. Asam stearat dan TEA membentuk garam TEA Stearat dengan reaksi netralisasi. Jumlah TEA yang ditambahkan mempengaruhi $\mathrm{pH}$ produk yang dihasilkan (Swarbick \& Boylan, 1996). Konsentrasi TEA yang digunakan pada F3 dan F7 paling tinggi dibanding formula lain yaitu mencapai 1,5\%. TEA merupakan basa kuat, sehingga dengan adanya konsentrasi TEA yang tinggi akan menyebabkan proses netralisasi semakin cepat terjadi menghasilkan $\mathrm{pH}$ yang semakin mendekati basa, dibuktikan dengan hasil uji $\mathrm{pH}$ sediaan yang mencapai $\mathrm{pH}$.

Uji tipe emulsi, menurut Goskonda (2009), TEA dicampur dengan asam stearat akan membentuk sabun anionik dengan $\mathrm{pH}$ sekitar 8 dan membentuk tipe emulsi tipe $\mathrm{m} / \mathrm{a}$ yang stabil dan halus. Hasil pengujian tipe emulsi terhadap 8 formula krim $o / w$ kombinasi oksibenzon dan titanium dioksida menunjukkan bahwa krim lebih terlarut saat diencerkan dalam air dibandingkan dalam minyak. Hanya fase luar emulsi yang dapat dilakukan pengenceran, sehingga dapat digunakan sebagai penanda tipe emulsi (Voigt, 1984).

Emulgator yang digunakan yaitu TEA Stearat merupakan emulgator yang larut dalam air. Banchroft rule menyatakan fase dimana emulgator larut adalah fase eksternal (Myers, 2006). Oleh sebab itu, terbukti bahwa krim yang dihasilkan memiliki tipe emulsi oil in water $(o / w)$ atau minyak dalam air (m/a).

\section{Penentuan Formula Optimum Krim $o / w$ Oksibenzon -Titanium Dioksida}

Berdasarkan hasil analistik statistik SLD, ketiga respon sifat fisik krim $o / w$ oksibenzon dan titanium dioksida yaitu viskositas, daya sebar, dan daya lekat memiliki model yang siginifikan dan lack of fit yang tidak signifikan. Oleh sebab itu, ketiga respon dapat digunakan sebagai parameter penentu formula optimum. Penetapan goal dilakukan berdasarkan nilai respon yang diharapkan. Goal untuk respon viskositas yaitu in range, daya sebar yaitu maximize, sedangkan daya lekat yaitu minimize. Derajat kepentingan yang digunakan adalah default $(+++)$. Nilai desirability yang dipilih adalah nilai tertinggi yaitu 0,975 dengan proporsi TEA.Stearat dan setil alkohol $8.93 \%$ dan 2.07\%. Software Design Expert version 9.0.4 memprediksikan nilai respon viskositas formula optimum sebesar 123,91 dPas; daya sebar sebesar $40,21 \mathrm{~cm}^{2}$; dan daya lekat sebesar 0,58 detik.

\section{Verifikasi Formula Optimum Krim o/w Oksibenzon dan Titanium Dioksida}

Verifikasi formula optimum krim o/w kombinasi oksibenzon dan titanium dioksida hasil prediksi dilakukan untuk mengetahui apakah nilai prediksi yang diberikan oleh software sesuai dengan nilai hasil percobaan yang sebenarnya. Prediksi respon sifat fisik formula optimum yang diperoleh dari analisis menggunakan software Design Expert version 9.0.4 selanjutnya dibandingkan dengan respon 


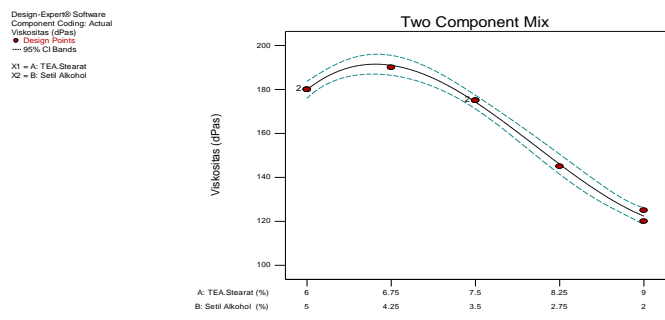

(a)
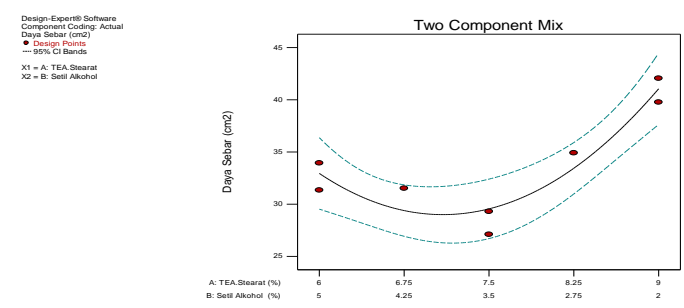

(b)

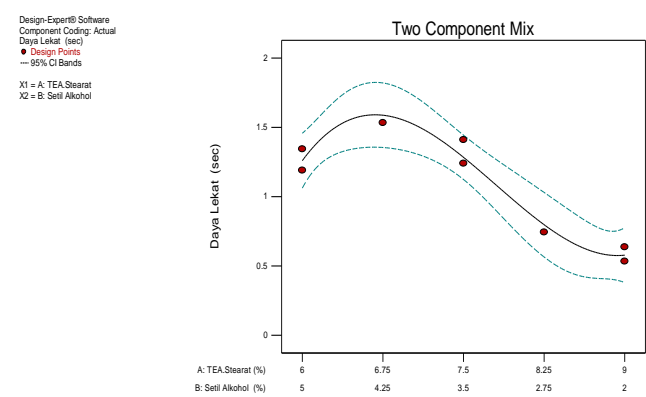

(c)

Gambar 1. Profil respon (a) viskositas; (b) daya sebar; (c) daya lekat

$$
\begin{array}{ll}
\text { Sifat Fisik } & : \text { Persamaan Simplex Lattice Design } \\
\text { Viskositas } & : Y=122,38 \mathrm{~A}+179,88 \mathrm{~B}+92,55 \mathrm{AB}-86,67 \mathrm{AB}(\mathrm{A}-\mathrm{B}) \\
\text { Daya Sebar } & : \mathrm{Y}=41,06 \mathrm{~A}+32,95 \mathrm{~B}-29,79 \mathrm{AB} \\
\text { Daya Lekat } & : \mathrm{Y}=0,58 \mathrm{~A}+1,26 \mathrm{~B}+1,46 \mathrm{AB}-2,40 \mathrm{AB}(\mathrm{A}-\mathrm{B})
\end{array}
$$

Keterangan $: \mathrm{A}=$ Fraksi komponen TEA. Stearat; $\mathrm{B}=$ Fraksi komponen setil alkohol

sifat fisik formula optimum yang diperoleh pada percobaan minggu ke-0 menggunakan software $\quad \mathrm{IBM}^{\circledR} \quad \mathrm{SPSS}^{\circledR}$ Statistic 16. Metode analisis statistik yang digunakan yaitu one sample t-test karena semua data terdistribusi normal.

Nilai respon viskositas, daya sebar, dan daya lekat formula optimum hasil percobaan menunjukkan hasil yang tidak berbeda signifikan dengan nilai prediksi software Design Expert version 9.0.4 ditunjukkan dengan nilai signifikansi ketiga respon viskositas, daya sebar, dan daya lekat $>0,05$. Dengan demikian, ketiga hasil respon uji sifat fisik memberikan data yang tidak berbeda signifikan sehingga persamaan dari software Design Expert version 9.0.4 pada metode Simplex Lattice Design dapat digunakan untuk memprediksi viskositas, daya sebar, dan daya lekat krim o/w kombinasi oksibenzon dan titanium dioksida dengan kombinasi variasi komponen TEA stearat dan setil alkohol.

\section{Penentuan Stabilitas Formula Optimum Krim $\quad 0 / w \quad$ Oksibenzon-Titanium Dioksida}

Formula optimum yang diperoleh kemudian diuji stabilitas fisiknya dengan cara melakukan uji sifat fisik krim setiap minggu selama penyimpanan 4 minggu. Uji stabilitas fisik meliputi uji viskositas, daya sebar, daya lekat, $\mathrm{pH}$, tipe emulsi, dan cycling test.

Viskositas, oksibenzon berbentuk serbuk sehingga pada penambahan ke dalam basis vanishing cream dengan 


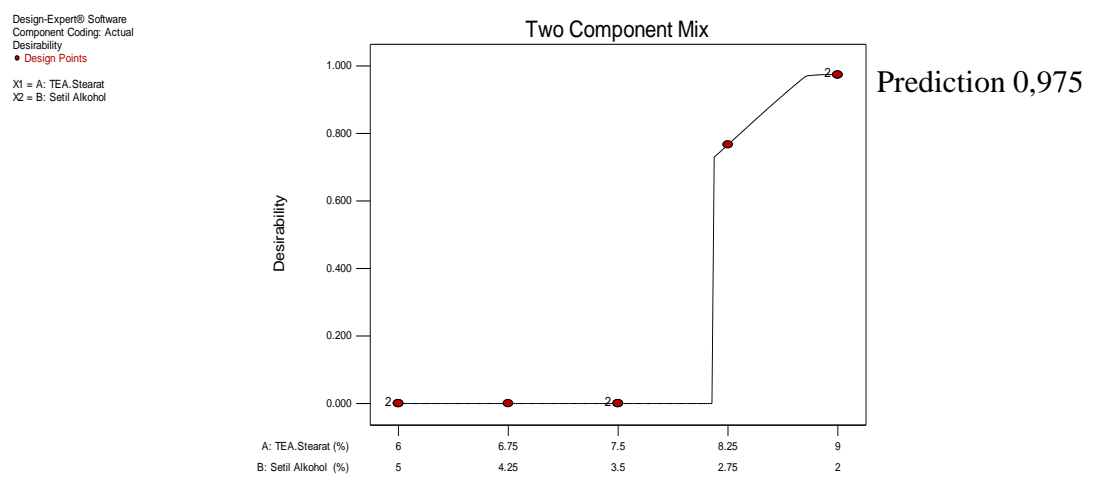

Gambar 2. Profil respon formula optimum

Tabel II. Hasil Uji One Sample T-Test Respon Prediksi Dibandingkan Respon Percobaan Formula Optimum Krim o/w Kombinasi Oksibenzon dan Titanium Dioksida

\begin{tabular}{ccccc}
\hline Sifat Fisik Krim & Prediksi & Percobaan & Sig. (2 tailed) & Interpretasi \\
\hline Viskositas (dPas) & 123,91 & 130 & 0,402 & Tidak berbeda signifikan \\
Daya Sebar (cm2) & 40,2 & 37,87 & 0,311 & Tidak berbeda signifikan \\
Daya Lekat (detik) & 0,58 & 0,57 & 0,075 & Tidak berbeda signifikan \\
\hline
\end{tabular}

Tabel III. Viskositas Selama 4 Minggu Penyimpanan

\begin{tabular}{cc}
\hline minggu ke- & Viskositas (dPAs) \\
\hline 0 & $130 \pm 10$ \\
1 & $123,33 \pm 20,82$ \\
2 & $123,33 \pm 11,55$ \\
3 & $133,33 \pm 20,82$ \\
4 & $133,33 \pm 20,82$ \\
\hline
\end{tabular}

konsentrasi tinggi menyebabkan kenaikan viskositas (Rosita et al., 2014). Nilai viskositas akan mempengaruhi daya sebar dan daya lekat dari sediaan (Ameliana et al., 2012).

Terjadi penurunan dan peningkatan viskositas yang fluktuatif. Peningkatan viskositas yang terjadi selama penyimpanan dapat diakibatkan oleh berflokulasinya globul dalam emulsi, sedangkan penurunan viskositas terjadi berkaitan dengan timbulnya pemisahan fase (Agoes, 2012). Panjang bagian hidrofobik memiliki efek yang sangat kuat dalam membentuk viskositas (Barmar et al., 2005). Rantai $\mathrm{CH}_{2}$ setil alkohol yang cukup panjang berkontribusi dalam peningkatan viskositas sediaan formula optimum krim $o / w$ kombinasi oksibenzon dan titanium dioksida.

Stabilitas fisik krim berdasarkan perubahan viskositas pada minggu ke-0 sampai minggu ke-4 dianalisis dengan IBM ${ }^{\circledR}$ SPSS ${ }^{\circledR}$ Statistic 16. Pertama, dilakukan uji normalitas untuk mengetahui pola distribusi data viskositas selama penyimpanan. Pengujian normalitas data viskositas menggunakan uji Shapiro Wilk karena jumlah data yang dianalisis kurang dari 50. Nilai signifikansi yang diperoleh dari uji Shapiro Wilk yaitu 0,187 ( $>0,05)$ yang artinya data viskositas terdistribusi secara normal. Apabila data terdistribusi secara normal, maka uji statistik dapat dilanjutkan dengan uji ANOVA. Uji ANOVA dilakukan untuk mengetahui apakah 
Tabel IV. Daya Sebar Selama 4 Minggu Penyimpanan

\begin{tabular}{cc}
\hline minggu ke- & Daya Sebar $\left(\mathbf{c m}^{\mathbf{2}}\right)$ \\
\hline 0 & $37,87 \pm 3,01$ \\
1 & $35,96 \pm 1,62$ \\
2 & $36,67 \pm 1,96$ \\
3 & $30,48 \pm 3,27$ \\
4 & $32,92 \pm 0,92$ \\
\hline
\end{tabular}

Tabel V. Daya Lekat Selama 4 Minggu Penyimpanan

\begin{tabular}{cc}
\hline minggu ke- & Daya Lekat (detik) \\
\hline 0 & $0,57 \pm 0,00$ \\
1 & $0,58 \pm 0,05$ \\
2 & $0,57 \pm 0,06$ \\
3 & $0,62 \pm 0,09$ \\
4 & $0,64 \pm 0,09$ \\
\hline
\end{tabular}

terdapat perubahan sifat fisik dari penyimpanan minggu ke-0 hingga minggu ke-4. Dari hasil analisis Homogenity of Variance menunjukkan nilai signifikansi $0,414(>0,05)$ yang artinya data viskositas memiliki varian yang sama. Oleh karena data viskositas identik, maka dilanjutkan analisis dengan One Way ANOVA. Hasil menunjukkan nilai signifikansi sebesar 0,903 $(>0,05)$ sehingga dapat dikatakan bahwa viskositas krim minggu ke-0 hingga minggu ke-4 tidak berbeda signifikan.

\section{Daya Sebar}

Nilai signifikansi yang diperoleh dari uji Shapiro Wilk yaitu 0,817 ( $>0,05)$ yang artinya data daya sebar terdistribusi secara normal. Dari hasil analisis Homogenity of Variance menunjukkan nilai signifikansi $0,296(>0,05)$ yang artinya data daya sebar memiliki varian yang sama. Oleh karena data daya sebar identik, maka dilanjutkan analisis dengan One Way ANOVA. Hasil menunjukkan nilai signifikansi sebesar $0,017(<0,05)$ sehingga dapat dikatakan bahwa daya sebar krim minggu ke-0 hingga minggu ke-4 berbeda signifikan.

Terjadi perbedaan sifat fisik daya sebar formula optimum krim $o / w$ kombinasi oksibenzon dan titanium dioksida selama penyimpanan. Kecepatan penyebaran bergantung pada viskositas formulasi, kecepatan penguapan pelarut, kecepatan peningkatan viskositas sebagai hasil dari penguapan, serta shearing stress yang dikenakan (Garg et al., 2002). Viskositas formula optimum krim $o / w$ kombinasi oksibenzon dan titanium dioksida cenderung mengalami peningkatan selama penyimpanan mengakibatkan daya sebar krim yang semakin menurun. Sifat fisik daya sebar formula optimum krim $o / w$ kombinasi oksibenzon dan titanium dioksida mengalami fluktuasi pada minggu ke-3, fluktuasi yang terjadi mungkin disebabkan oleh sifat daya sebar krim $o / w$ kombinasi oksibenzon dan titanium dioksida yang dipengaruhi oleh komposisi komponen TEA stearat, serta alat daya uji yang kurang presisi.

Metode ekstonsiometer pelat sejajar adalah metode yang paling banyak digunakan untuk menentukan dan mengukur daya sebar sediaan semi padat. Keuntungan dari metode ini yaitu sederhana dan relatif murah. Namun di sisi lain, metode ini tidak teliti dan sensitif, dan data yang dihasilkannya harus secara manual ditafsirkan dan disajikan (Jelvehgari et al., 2007). 


\section{Daya Lekat}

Nilai signifikansi yang diperoleh dari uji Shapiro Wilk yaitu 0,072 $(>0,05)$ yang artinya data daya lekat terdistribusi secara normal. Dari hasil analisis Homogenity of Variance menunjukkan nilai signifikansi $0,104(>0,05)$ yang artinya data daya sebar memiliki varian yang sama. Oleh karena data daya sebar identik, maka dilanjutkan analisis dengan One Way ANOVA. Hasil menunjukkan nilai signifikansi sebesar $0,686(>0,05)$ sehingga dapat dikatakan bahwa daya lekat krim minggu ke-0 hingga minggu ke-4 tidak berbeda signifikan. Sifat fisik daya lekat krim $o / w$ kombinasi oksibenzon dan titanium dioksida serupa dengan sifat fisik viskositas. Viskositas formula optimum krim $o / w$ kombinasi oksibenzon dan titanium dioksida cenderung mengalami peningkatan selama penyimpanan. Hal serupa juga terjadi pada daya lekat formula optimum krim $o / w$ kombinasi oksibenzon dan titanium dioksida.

\section{Tipe Emulsi}

Inversi adalah peristiwa berubahnya tipe emulsi dari tipe $\mathrm{M} / \mathrm{A}$ menjadi $\mathrm{A} / \mathrm{M}$ atau sebaliknya (Anief, 1999). Emulsi krim yang stabil harus mampu mempertahankan tipe emulsinya selama penyimpanan. Pengujian tipe emulsi selama 4 minggu penyimpanan menunjukkan bahwa formula optimum tidak mengalami perubahan tipe emulsi. Formula optimum setelah penyimpanan tetap terencerkan saat dilarutkan dalam media air menandakan bahwa krim formula optimum stabil dalam penyimpanan. Hal ini mungkin disebabkan oleh kecepatan homogenisasi yang tepat selama formulasi emulsi sehingga mencegah kerusakan dari formulasi selama pengujian (Abdurahman \& Rosli, 2006).

$\mathrm{pH}$, bagian terpenting dalam stabilitas kimia sediaan adalah performa saat pengujian dipercepat dan profil kinetika pH (Issa et al., 2000). Agar suatu formulasi memperoleh pengakuan dalam industri, formulasi tersebut harus memiliki $\mathrm{pH}$ yang dekat dengan kisaran $\mathrm{pH}$ normal kulit manusia (Matousek et al., 2003). Hasil pengujian formula optimum krim $o / w$ kombinasi oksibenzon dan titanium dioksida menunjukkan $\mathrm{pH}$ yang stabil pada penyimpanan minggu ke-0, 1,2, 3, 4 .

Cycling test, uji stabilitas dipercepat cycling test dilakukan dengan mengondisikan sediaan krim pada siklus panas $\left(45^{\circ} \mathrm{C}\right)$ dan dingin $\left(4^{\circ} \mathrm{C}\right)$ yang ekstrim secara bergantian (Amnuaikit \& Boonme, 2015). Dengan cara ini diperoleh gambaran stabilitas sediaan krim pada kondisi penyimpanan jangka panjang dalam waktu uji yang dipercepat. Hasil cycling test formula optimum $\mathrm{krim} o / w$ kombinasi oksibenzon dan titanium dioksida tidak mengalami pemisahan fase setelah melewati 6 siklus cycling test. Emulgator TEA stearat mampu menghasilkan lapisan antarmuka yang kompleks dan rapat yang tidak dipengaruhi siklus suhu pada kondisi dipercepat menghasilkan krim yang stabil pada cycling test.

Uji aktivitas tabir surya secara In Vivo, uji aktivitas formula optimum krim $o / w$ kombinasi oksibenzon dan titanium dioksida secara in vivo dilakukan dengan mengukur aktivitas daya perlindungan krim tabir surya terhadap kelinci betina galur New Zealand White. Kelinci diinduksikan dengan senyawa 8metoksiprosalen sebelum penyinaran untuk meningkatkan sensitivitas hewan uji terhadap paparan lampu UV B. Hewan uji yang dipilih berjenis kelamin wanita dengan asumsi bahwa krim $o / w$ kombinasi oksibenzon dan titanium dioksida akan banyak digunakan oleh konsumen wanita. Punggung kelinci dicukur ditandai dengan luas $5 \times 5 \mathrm{~cm}^{2}$. Meskipun radiasi dari emisi lampu cahaya buatan lebih rendah dibandingkan dengan matahari, namun karena penyinaran dilakukan terus menerus, kulit tidak dapat memperbaiki diri seperti yang seharusnya (Tian et al., 2014). Oleh sebab itu, penggunaan radiasi 
Tabel I. Hasil Pengamatan MED pada Punggung Kelinci Terinduksi 8-MOP

\begin{tabular}{|c|c|c|c|c|c|c|c|}
\hline \multirow{2}{*}{ Perlakuan } & \multicolumn{6}{|c|}{ Waktu Penyinaran (menit) } & \multirow{2}{*}{ Nilai SPF } \\
\hline & 20 & 30 & 60 & 120 & 180 & 240 & \\
\hline Tanpa & + & 0 & 0 & 0 & 0 & 0 & 0 \\
\hline Kontrol Negatif & + & 0 & 0 & 0 & 0 & 0 & 1 \\
\hline F. Optimum & - & - & - & - & - & + & 12 \\
\hline
\end{tabular}

Keterangan: (-) : belum timbul eritema; (+) : sudah timbul eritema; 0 : tidak dilakukan penyinaran lagi

dari lampu UV B dapat menggambarkan kondisi eritema kulit seperti saat terpapar sinar matahari.

Senyawa 8-metoksiprosalen susah larut dalam akuades. Oleh sebab itu, 8metoksiprosalen disuspensikan dalam PGA 2\%. PGA 2\% akan membantu kelarutan senyawa 8-metoksiprosalen. Larutan ini kemudian diinduksikan dengan cara per oral karena bentuk larutan suspensi tidak boleh diinjeksikan karena mengandung partikel tidak terlarut yang dapat menyumbat pembuluh darah. Senyawa 8metoksiprosalen mencapai bioavailibilitas maksimumnya 1,5-3 jam setelah pemberian secara oral dan bertahan sampai 8 jam (Sekardani, 2011). Dosis pemberian 8metoksiprosalen adalah $10 \mathrm{mg} / \mathrm{kgBB}$.

Nilai SPF dihitung dengan cara membandingkan Minimal Erythema Dose (MED) pada kulit yang terlindung tabir surya dibandingkan MED yang sama pada kulit yang tidak terlindungi. Banyaknya $\mathrm{krim}$ yang dioleskan yaitu $2 \mathrm{mg} / \mathrm{cm}^{2}$ (Kim et al., 2010). Penelitian terdahulu yang dilakukan oleh Faurschou dan Wulf membuktikan bahwa hasil nilai SPF menunjukkan SD yang tinggi ketika dosis 0,5; 1,0; dan 4,0 $\mathrm{mg} / \mathrm{cm}^{2}$ diaplikasikan, sedangkan menghasilkan SD yang relatif rendah ketika 2,0 $\mathrm{mg} / \mathrm{cm}^{2}$ diaplikasikan (Faurschou \& Wulf, 2007).

Nilai MED pada kulit yang tidak terlindung formula optimum krim $o / w$ kombinasi oksibenzon dan titanium dioksida didapatkan berdasarkan hasil orientasi. Hasil orientasi menunjukkan bahwa eritema muncul pada punggung kelinci setelah 20 menit penyinaran dan diamati setelah 24 jam. Ketiga kelinci menunjukkan hasil yang sama sehingga dapat dikatakan bahwa nilai MED pada punggung kelinci yang tidak terlindung krim tabir surya adalah 20 menit.

Pengujian nilai SPF kemudian dilanjutkan dengan pengolesan kontrol negatif berisi basis krim tanpa kandungan zat aktif tabir surya sebagai pembanding serta formula optimum krim $o / w$ kombinasi oksibenzon dan titanium dioksida. Awal penyinaran dimulai pada waktu MED kelinci tanpa perlakuan yaitu 20 menit. Punggung kelinci yang diolesi dengan kontrol negatif yaitu basis krim menunjukkan hasil bahwa pada 20 menit penyinaran menyebabkan munculnya eritema pada punggung kelinci. Hal ini berarti bahwa kontrol negatif yaitu basis krim tanpa kandungan zat aktif tabir surya tidak mampu memberikan perlindungan terhadap paparan sinar UV, sama halnya dengan timbulnya eritema pada punggung kelinci tanpa perlakuan. Penelitian dilanjutkan dengan penyinaran pada punggung kelinci yang diolesi fomula optimum krim $o / w$ kombinasi oksibenzon dan titanium dioksida. Awal penyinaran dimulai pada waktu MED kelinci tanpa perlakuan yaitu 20 menit, kemudian dilakukan penambahan waktu penyinaran secara bertahap setiap 1 jam. Hasil pengujian nilai SPF (Tabel VI) memberikan hasil bahwa formula optimum krim $o / w$ kombinasi oksibenzon dan titanium dioksida mampu memberikan perlindungan terhadap punggung kelinci 
yang dipapari sinar UVB sampai dengan 4 jam.

Banyak faktor yang mempengaruhi efek tabir surya, seperti kemampuan penyerapan kulit, frekuensi aplikasi, kepadatan, basis tabir surya, serta terutama jumlah tabir surya yang diaplikasikan (Kim et al., 2010). Berdasarkan hasil percobaan diketahui bahwa nilai SPF formula optimum krim $o / w$ kombinasi oksibenzon dan titanium dioksida yaitu 12 .

Tipe aktivitas tabir surya terkait dengan panjang gelombang serapan maksimum dan hal ini akan tergantung pada khromofor pada setiap senyawa tersebut (Sastrohamidjojo, 1991). Oksibenzon memiliki gugus kromofor yaitu pada gugus cincin karbonil yang mampu menangkap sinar UV sehingga mampu memberi daya perlindungan terhadap paparan sinar UV. Serapan UV A dan UV B dipengaruhi oleh gugus metoksi dan substituen cincin oksibenzon (Correa et al., 2012). Titanium dioksida menangkal sinar UV dengan cara memantulkan sinar UV yang datang.

Kombinasi antara oksibenzon dan titanium dioksida menghasilkan nilai SPF yang lebih tinggi dari penggunaan oksibenzon secara tunggal. Namun, kombinasi oksibenzon 6\% dengan titanium dioksida $5 \%$ belum menghasilkan nilai SPF 15 yaitu nilai SPF minimal yang diijinkan pada produk sediaan tabir surya yang beredar di pasaran.

Penelitian yang dilakukan (El-Boury et al., 2007) tentang perhitungan nilai SPF secara in vitro kombinasi berbagai senyawa tabir surya kimia dan tabir surya fisik pada konsentrasi tertinggi masing-masing senyawa tabir surya yang diperbolehkan oleh regulasi, salah satunya kombinasi oksibenzon dengan konsentrasi $10 \%$ dan titanium dioksida $25 \%$ menghasilkan nilai SPF sebesar 39,07 \pm 4,11. Upaya peningkatan nilai SPF sediaan tabir surya dapat ditingkatkan dengan meningkatkan konsentrasi tabir surya fisik ataupun menambahkan jenis tabir surya kimia lainnya sehingga dapat dihasilkan sediaan tabir surya dengan nilai SPF 15 atau lebih.

\section{KESIMPULAN}

Proporsi TEA stearat dan setil alkohol yang menghasilkan formula optimum krim $o / w$ kombinasi oksibenzon dan titanium dioksida adalah $8.93 \%$ dan $2.07 \%$. Formula optimum krim $o / w$ kombinasi oksibenzon dan titanium dioksida selama penyimpanan 4 minggu menghasilkan sediaan krim yang stabil pada respon sifat fisik viskositas dan daya lekat, namun tidak pada respon sifat fisik daya sebar. Nilai SPF formula optimum krim $o / w$ kombinasi oksibenzon dan titanium dioksida hasil uji aktivitas tabir surya secara in vivo adalah 12 .

\section{DAFTAR PUSTAKA}

Abdurahman, H. N. \& Rosli, M. Y., 2006, Stability Investigation of Water-inCrude Oil Emulsion, Journal of Applied Science, 6, 2895-2900.

Agoes, G., 2012, Sediaan Farmasi LikuidaSemisolida (SFI-7), Penerbit ITB, Bandung.

Ameliana, L., Oktora, L. \& Maharani, Z., 2012, Optimasi Komposisi Asam Laktat dan Zink Oksida dalam Krim Tabir Surya Kombinasi Benzophenone-3 dan Octyl methoxycinnamate, Skripsi, Fakultas Farmasi Universitas Jember, Jember.

Amnuaikit, T. \& Boonme, P., 2015, Formulation and Characterization of Sunscreen Creams with Synergistic Efficacy on SPF by Combination of UV Filters, Journal of Applied Pharmaceutical Science, 3(8), 001005.

Anief, M., 1999, Sistem Dispersi, Formulasi Suspensi dan Emulsi, Gadjah Mada University Press, Yogyakarta.

Ansel, H. C., 2005, Pengantar Bentuk Sediaan Farmasi, Edisi IV, Penerbit UI, Jakarta.

Aulton, M. E., 2002, Pharmaceutics : The Science Dosage Form Design, $2^{\text {nd }}$ Ed., 
Ed. Harcourt Publisher, New York .

Barmar, M., Barikani, M. \& Kaffashi, B., 2005, Steady Shear Viscosity Study of Various HEUR Models with Hydrophilic and Hydrophobic Sizes, Colloids and Surfaces $A$ : Physicochemical and Engineering Aspects, 253, 77-82.

Baughman, B. M. et al., 2009, Structural and Spectroscopic Studies of the Photophysical Properties of Benzophenone Derivatives, The Journal of Physical Chemistry A, 113(28), 8011-8019.

Benson, H., 2007, Sunscreen : Efficacy, Skin Penetration, and Toxicological Aspects. Dalam: K. Walters \& M. Roberts, Dermatologic, Cosmeceutic, and Cosmetic Development, 419-435, Informa Healthcare, USA.

Correa, B. A. M. et al., 2012, Molecular Modeling Studies of the Structural, Electronic, and UV Absorption Properties of Benzophenone Derivatives, The Journal of Physical Chemistry A, 116, 10927-10933.

Diaz-Cruz, M. S., Llorca, M. \& Barcelo, D., 2008, Organic UV Filters and Their Photodegradates, Metabolites, and Disinfection By-Products in the Aquatic Environment. Trends in Analytical Chemistry, 27.

Draelos, Z. D. \& Thaman, L. A., 2006, Cosmetic Formulation of Skin Care Products, Informa Healthcare USA, Inc., New York.

El-Boury, S. et al., 2007, Effect of The Combination of Organic and Inorganic Filters on the Sun Protection Factor (SPF) Determined by In Vitro Method, International Journal of Pharmaceutics, 1-5.

Faurschou, A. \& Wulf, H., 2007, The Relation Between Sun Protection Factor and Amount of Sunscreen Applied In Vivo, British Journal of Dermatology, 156, 716-719.

Garg, A., Aggarwal, D., Garg, S. \& Singla, A., 2002, Speading of Semisolid
Formulation : An Update, Pharmaceutical Technology, 84-102. Goskonda, S. R., 2009, Dalam: R. C. Rowe, P. J. Sheskey \& M. E. Quinn, Handbook of Pharmaceutical Excipients, 754-755, Pharmaceutical Press and American Pharmacists Association, USA.

Sunscreen Protection, Journal of Dermatology, 20, 112-119.

Hanson, K. M., Gratton, E. \& Bardeen, C. J., 2006, Sunscreen Enhancment of UVinduceed Reactive Oxygen Species in the Skin, Free Radical Biology \& Medicine Journal, 41, 1205.

Holick, M., MacLaughlin, J., Clark, M. \& Holick, S., 1980, Photosynthesis of Previtamin D3 in Human Skin and the Physiologic Consequences, Science 210, 203-205.

Hussein, M. R., 2005, Ultraviolet Radiation and Skin Cancer: Molecular Mechanisms, Journal of Cutaneous Pathology , 3, 191-205.

Issa, T. S. et al., 2000. Improved Kinetic Parameter Estimation in pH-Profile Data, International Journal of Pharmaceutics, 198, 39-49.

Jellinek, J. S., 1970, Formulation and Function of Cosmetics, WileyInterscience, New York.

Jelvehgari, M., Rashidi, M. R. \& Mohammadi, S. H. M., 2007, Adhesive and Spreading Properties of Pharmaceutical Gel Composed of Cellulose Polymer, Jundishapur Journal of Natural Pharmaceutical Products, 2(1), 45-58.

Kim, S. \& Choi, K., 2014, Occurrences, Toxicities, and Ecological Risks of Benzophenone-3, A Common Component of Organic Sunscreen Products: A Mini-Review, Environment International, 70, 143157.

Kim, S. M. et al., 2010, The Relation Between the Amount of Sunscreen Applied and the Sun Protection Factor in Asian Skin, Journal of the American Academy Dermatology, 62(2), 218-222. 
Kurniawan, D. W. \& Sulaiman, S., 2009, Teknologi Sediaan Farmasi, Edisi IV, Graha Ilmu, Yogyakarta.

Lachman, L., Lieberman, H. A. \& Kanig, J. L., 1994, Teori dan Praktek Farmasi Industri II, Edisi III, Universitas Indonesia Press, Jakarta.

Langenbucher \& Lange, 2007, Teori dan Praktek Farmasi Industri II . Edisi III, Universitas Indonesia Press, Jakarta.

Martin, A., Swarbick, J. \& Cammarata, A., 1993, Farmasi Fisik 2, Edisi II, Universitas Indonesia Press, Jakarta.

Marchaban, Fudholi, A., Sulaiman, T.N.S., Mufrod, Martin, R., Bestari, A.N., 2015, Seri Buku Petunjuk Praktikum Teknologi Farmasi: Teknologi Formulasi Sediaan Cair Semi Padat, Laboratorium Teknologi Farmasi Fakultas Farmasi UGM, Yogyakarta.

Matousek, J. L. et al., 2003, Evaluation of the Effect of pH on In Vivo Growth of Malassezia Pachydermatis, Canadian Journal of Veterinary Research, 67, 5659.

Myers, D., 2006, Surfactant Science and Technology, $3^{\text {rd }}$ Ed., John Willey and Sons Inc., New Jersey.

Ningrum, A. A., 2011, Optimasi Proses Pencampuran Hand Lotion dengan Kajian Kecepatan Putar Mixer, Suhu, dan Waktu Pencampuran Menggunakan Metode Desain Faktorial, Skripsi, Universitas Sanata Dharma, Yogyakarta.

Osterwalder, U. \& Herzog, B., 2009, Sun Protection Factor : World Wide Confusion, British Journal of Dermatology, 161 (3), 13-24.

Rosita, M. R. E., Murrukmihadi, M. \& Suwarmi, 2014, Pengaruh Kombinasi Oxybenzone dan Octyl Methoxycinnamate (OMC) pada Karakteristik Fisik dan SPF dalam Sediaan Krim Tabir Surya, Majalah Farmaseutik, 10(1), 182-186.
Rowe, R., Sheskey, P. J. \& Owen, S. C., 2005, Handbook of Pharmaceutical Excipients, 5th Ed., Pharmaceutical Press, London.

Sambandan, D. R. \& Ratner, D., 2011, Sunscreens : An Overview and Update, Journal of the American Academy of Dermatology, 64, 748758.

Sastrohamidjojo, H., 1991, Spektroskopi, Liberty, Yogyakarta.

Sekardani, N. I., 2011, Stabilitas Fisik Sediaan Krim Pati Bengkuang (Pachyrhizus erosus (L.) Urban) dan Aktivitasnya Sebagai Tabir Surya pada Mencit, Skripsi, Fakultas Farmasi Univeristas Gadjah Mada, Yogyakarta.

Sheu, M. T. et al., 2003, Correlation of In vivo and In vitro Measurements, Journal of Food and Drug Analysis, 11(2), 128132.

Sinko, P. J., 2006, Physical Pharmacy and Pharmaceutical Sciences, $5^{\text {th }}$ Ed., Lippincott William \& Wilkins, Philadelphia.

Sliney, D. H., 2001, Photoprotection of the Eye UV Radiation and sunglasses, Journal Photochemical \& Photobiology B, 64, 166-175.

Smith, E. W., Maibach, H. I. \& Surber, C., 2000, Use of Emulsions as Topical Drug Delivery Systems, In: F. Nielloud \& G. Marti-Mestres, (Ed.), Pharmaceutical Emulsions and Suspensions, 259-270, Marcel Dekker, New York.

Swarbick, J. \& Boylan, J. C., 1996, Encyclopedia of Pharmaceutical Technology, 14th Ed., Marcel Dekker Inc., New York.

Swarbrick, J. \& Boylan, J., 1995, Percutaneous Absorption, Dalam: Encyclopedia of Pharmaceutical Technology, 413-445, Marcel Dekker Inc., New York.

Tian, Y. etal., 2014, The Injury and 
Cumulative Effects on Human Skin by UV Exposure from Artificial Fluorescence Emission, Photochemistry and Photobiology, 90,
1433-1438.

Voigt, R., 1984, Buku Pelajaran Teknologi Farmasi, Edisi V, Gadjah Mada University Press, Yogyakarta. 